\section{The Eosinophil Leucocytes}

By Dr. R. K. Archer. Pp. xiv + 205. (Oxford: Blackwell Scientific Publications, 1963.) 40s. net.

A LTHOUGH the characteristic staining properties of A eosinophil leucocytes, first described by Ehrlich in 1879 , and the striking electron-dense inclusions revealed by the electron microscope within the eosinophil granules of many species, render these cells relatively easy to identify and investigate, their functions are still by no means clear. A monograph with a functional approach is therefore particularly welcome.

After an introductory discussion of some of the problems surrounding the eosinophils, Dr. Archer reviews the experimental work which he has carried out over the past eight years at the Equine Research Station at Newmarket and discusses his findings in relation to the work of other investigators. A major contribution has been in the development of a method for isolating viable horse or human eosinophils from normal blood at about 80 per cent purity. He shows that such cell-preparations and the extracts made from them are capable of antagonizing some of the effects of histamine in vivo, as well as interacting with histamine in vitro. He also shows that, in the horse, injection of histamine into the tissues is rapidly followed by an eosinophilia in the region concerned and that this effect is reduced or abolished by antihistamine compounds. Evidence is also presented that eosinophil leucocytes antagonize the œdema-forming properties of 5-hydroxytryptamine, although this substance has no chemotactie attraction for eosinophils.

In the interpretation of his findings, Dr. Archer takes up the suggestion that eosinophils have the function of inactivating histamine, and argues cogently that, on the basis of the chemotactic effects of histamine, such phenomena as corticoid-induced eosinopenias and the eosinophilias observed in foreign protein reactions and in parasitic states could readily be explained. Whatever reservations may be entertained with regard to this hypothesis, it has the very real value of indicating lines of investigation which are likely to throw further light on the functions of the eosinophils. The monograph can be confidently recommended to all whose interests lie in this and allied fields.

G. HuDsoN

\section{General Microbiology}

By Prof. Roger Y. Stanier, Prof. Michael Doudoroff and Prof. Edward A. Adelberg. Second edition. Pp. xiii + 753. (London: Macmillan and Co., Ltd., 1963.) 50s. net. THE first edition of this work was reviewed in Nature under its American title The Microbial World in 1957. Since then there have been many additions to our knowledge of the fundamentals of microbiology, and it is to the credit of the authors that they have been able to keep this edition within the bounds of an increase of only fifty-one pages. The book maintains its attractive format. instructive diagrams, and clear photographs. The authors have rearranged the material considerably: the section on "The Biological Background" has been deleted and much of the information that it contained is distributed among the different chapters of the new book. The section on "Microscopy" has been relegated to an appendix, which in my view is an advantage. The chapter on bacterial diseases of plants has been deleted.

The book remains a very excellent introduction to general microbiology. The basic ideas of bacterial genetics and biochemistry are clearly and attractively presented. It is, however, curious that a book of this kind published in 1963 should contain no reference to the recent work on the nature of the DNA code for aminoacids.

The chapters on microbial pathogenicity, inducible host resistance, and infectious diseases are the least satisfactory. There is no reference to Dubos's work on the biochemical determinants of pathogenicity, and no men- tion of the cases where specific biochemical lesions have been shown to be caused by toxic metabolites of bacteria is made. The section on immunology ignores the whole field of comparative immunology completely and the section on the production of antibodies makes no reference to the recent work of Fishman. These chapters contrast sharply with the imaginative approach of the greater part of the book, and it is to be hoped that in a future edition the editors will rewrite them so as to make them as illustrative of general biological principles as the earlier chapters of the book.

PATRICK COLLARD

Common Malayan Plants

By Prof. H. B. Gilliland. Second edition. Pp. viii +228 . (Kuala Lumpur: University of Malaya Press, 1962. 13s.6d. DURING the Japanese occupation of the Singapore Botanic Gardens, several hundred drawings of Malayan plants were published in a two-volume work printed in Japanese, entitled (in translation) "Illustrations of Useful Plants of the Southern Regions". This work is now rare, but in 1958 Prof. Gilliland published a selection of more than 200 of these drawings in a small popular book for the non-specialist who is interested in Malayan plants. The present edition differs only from the earlier one in its slightly larger format, although the illustrations are of the same size.

Each of the line-drawings bears the family and specific names of the plant, omitting authorities, and also the vernacular name. A very brief note is given describing the plant and its habitat. The drawings present a reasonable likeness to the plants, but they are mostly lacking in finish. The alphabetical arrangement of the plants by generie names, which will be largely unknown to the intended reader, is surely a disadvantage in a book of this kind. As a result, Amomum and Zingiber, for example, are widely separated, and unfortunately there is no index to indicate what other genera of the ginger-family might be represented. As one of the few popular books concerning Malayan plants, the value of this work would be considerably increased if the illustrations were in some systematic order, so that the plants of one family were together. Indexes are provided to English and Malayan plant-names with their equivalent Latin generic names.

L. L. FORMAN

British Compounding Ingredients for Rubber Compiled by Brian J. Wilson. Second edition. Pp. xxiii + 596. (Cambridge; W. Heffer and Sons Ltd., 1964.) 84s.

THIS is the second edition of an already successful

book on the chemical composition, physical properties, uses and suppliers of compounding ingredients. Needless to add, it contains a greatly increased number of products. It is a useful reference book and fulfils all the promise which one has been led to expect from a project sponsored by the Rubber and Plastics Research Association.

Apart from an explanatory introduction and brief, but excellent, chapters on natural rubbers and British Standards of interest, the book is divided into four main parts, namely, compounding ingredients for dry rubbers and latices special products and indexes. One of its attractive features is the concise notes on the use of the products compared with the often too long descriptions put forward by the sellers.

The need for the second edition can be realized by a study of the chapter on "Synthetic Rubbers and Latices". The new edition covers nearly ten times the number of products contained in the first edition. The qualities of the paper, printing, lay-out and binding leave nothing to be desired.

It is an indispensable book for rubber chemists, rubber compounders and purchasing staff. As a source of information on competitive products it should be in the possession of every producer and salesman of rubber-compound$\begin{array}{ll}\text { ing ingredients. } & \text { W. J. S. NAUNTON }\end{array}$ 